\title{
Central Blindness Associated with a Pituitary Adenoma in a Mare
}

\author{
Cegueira de origem central associado a adenoma de pars intermedia de hipófise em uma égua
}

\author{
Yasmin Daoualibi', Juliana Ferreira Rocha', Natália Braz' ', Marilene de Farias Brito', \\ Luciano da Silva Alonso² \& Daniel Guimarães Ubiali'
}

\begin{abstract}
Background: Pituitary pars intermedia (PI) adenoma is a benign adenohypophysis neoplasm, rare in Brazil, which may compress adjacent structures and lead to dysfunctions of the endocrine organs. The most affected species are equines, particularly aged animals. This neoplastic disease is often associated with Cushing's syndrome, when the pituitaryadrenocortical axis is affected. However, this neoplasm is seldom associated with clinical blindness. This paper describes a case of pituitary pars intermedia (PI) adenoma which caused blindness in a mare.

Case: An emaciated, blind mare that had difficulty finding water and food was referred to "Hospital Veterinário de Grandes Animais" of "Universidade Federal Rural do Rio de Janeiro", in Seropédica, state of Rio de Janeiro, Brazil, and later to the "Setor de Anatomia Patológica" (SAP/UFRRJ) for necropsy. During necropsy it was found that the animal's pituitary gland consisted of a circumscribed globous mass measuring $3.5 \times 2.5 \times 2.5 \mathrm{~cm}$, symmetrical and well delimited at the sella turcica. Several organs were collected, fixed in $10 \%$ formalin and then processed for histological examination. The brain was subjected to serial cleavage along the path of the vision organs. All collected tissues were stained with hematoxylin and eosin; the pituitary was stained with Schiff Periodic Acid (PAS) to differentiate neoplastic cells and with Luxol Fast Blue to evidence demyelination. Histopathology found that the pars intermedia (PI) was thickened and compressed the neurohypophysis and adenohypophysis. Cells were arranged in a disorganized manner or formed follicles or cysts containing eosinophilic material (colloid), with granules strongly positive after staining with PAS. Proliferated cells were large, polyhedral to ovoid, and contained clear basophilic granular material. The nuclei were spherical to ovoid and there were mild anisocytosis and anisocariasis. Cysts were frequently found in the pars intermedia (PI) and occasionally in the pars distalis. Mitoses were rare. In some areas of the pars intermedia (PI), cells were arranged in a solid manner forming spherical sub-nodules. An orange yellow pigment was observed in the pericary (lipofuscinosis) in various neurons of several areas of the central nervous system and of the trigeminal ganglion. In the optic tract, there were areas with moderate demyelination, evidenced by Luxol Fast Blue staining, and macrophages characterizing the so-called digestion chambers. In the right and left lateral geniculate nuclei a focal area of neurons with shrunken hypereosinophilic pericarion and pyknotic nuclei (neuronal death) and atypical and reactive astrocytes was observed, with increased volume, evident cytoplasm and nuclei with marginated chromatin which was sometimes reniform.

Discussion: This paper presents the pathological findings obtained from a mare with central blindness due to pituitary pars intermedia adenoma. The analysis of the structures affected and correlation of alterations with the respective clinical signs are compared with alterations in other areas of the pituitary which generate clinical signals not observed in this mare, but which occur more often in equines with tumors in that organ. Thus, central and bilateral blindness was associated with compression of the optical tracts by the neoplastic mass and consequent death of neurons of the lateral geniculate nucleus. Pituitary PI adenoma should be considered as a differential diagnosis for blindness.
\end{abstract}

Keywords: pituitary, horse, pars intermedia adenoma, blindness.

Descritores: pituitária, equinos, adenoma de pars intermedia, cegueira.

DOI: $10.22456 / 1679-9216.100106$

Accepted: 24 February 2020

Published: 15 March 2020 


\section{INTRODUCTION}

Pituitary pars intermedia adenoma is a benign, slow-growing progressive neoplasia that affects the adenohypophysis and leads to an increase in its volume. This causes compression of adjacent structures and/or dysfunction of other endocrine organs [6,7]. This neoplasia has been described in horses, dogs, and mice [23]. In horses, age is the predisposing factor that should be taken into account the most. This neoplasia has been regarded as important in many countries, as many owners today raise horses to a very advanced age $[6,7]$. The most common findings related to this pituitary tumor in horses are associated with Cushing's syndrome, resulting from a dysfunctional pituitary-adrenal axis [19]. Blindness is rarely a clinical sign associated with pituitary adenomas in horses; it occurs in cases where the neoplasm compresses the optic tract, chiasm, and nerve [26]. Neurological disorders are often fatal and represent one of the most common causes of euthanasia in horses $[14,15]$. Blindness caused by compression of the brain is considered a rare diagnosis in Brazil $[4,13,14]$. This paper aims to report a case of pituitary pars intermedia adenoma that caused blindness in an equine.

\section{CASE}

On January 19, 2015 an 18-year-old mare of the Campolina breed was seen at the "Hospital Veterinário de Grandes Animais" of the Universidade Federal Rural do Rio de Janeiro (UFRRJ), presenting acute blindness. The owner provided the animal's record. The mare was euthanized and necropsied by the team of the "Setor de Anatomia Patológica" (SAP/ UFRRJ) on January 20th, 2015. The mare presented good body condition ( $450 \mathrm{~kg}$, BCS 5/9). The vital signs were within the normal ranges - heart rate of 44 beats per minute, respiratory rate of 18 breaths per minute, and rectal temperature of $37.8^{\circ} \mathrm{C}$.

The mare presented emaciation, blindness, difficulty in grazing and finding water. The record showed that from the age of 10 the mare had been placed with stallions, but never bred. After withdrawal from the troop, the animal was referred to assisted reproduction; however, it did not respond to the reproduction protocols adopted. The mare did not present signs of systemic disorder, but also did not respond to the menace reflex ophthalmic examinations. Pupillary direct and consensual light reflexes were deficient for both eyes. The other neurological exams come out normal.
The necropsy found that the pituitary gland consisted in a circumscribed, symmetrical, well-defined $3.5 \times 2.5 \times 2.5 \mathrm{~cm}$ globular mass in the sella turcica. The pituitary, trigeminal ganglion, brain, spinal cord, thyroid and adrenal glands, ovaries, and fragments of the spleen, heart, kidney, lungs, liver, intestines, stomach, bladder, and pancreas were fixed in $10 \%$ formalin for histopathology. No morphological changes were observed in the eye globes.

The central nervous system was histologically evaluated, including areas of the visual pathway: optic nerve, optic chiasm, lateral geniculate nuclei, rostral and caudal colliculi, occipital cortex, frontal cortex, parietal cortex, temporal cortex, basal nuclei, thalamus, hippocampus, pons, medulla oblongata, cerebellum, and cervical, thoracic and lumbar spinal cords. Hematoxylin and eosin staining were performed on all tissue fragments collected. The pituitary was additionally stained by the periodic acid Schiff (PAS) method to differentiate neoplastic cells and the Luxol Fast Blue method to detect demyelination. The pituitary presented histological PI (pars intermedia) thickening and compression of the pars distalis and pars nervosa. The proliferated cells were large, polyhedral to columnar, and contained basophilic and clear granular cytoplasmic material. The nuclei were spherical to ovoid. Moderate anisocytosis and anisokaryosis were found. The cells were arranged in a disorganized manner or forming follicles or cysts containing eosinophilic material (colloid), with strongly PAS-positive granules. The PI cells were also positive, having been stained in purple. Cysts were often found in the PI and occasionally in the pars distalis. Mitoses were uncommon, fewer than one per higher magnification field. In some areas of the PI, the cells were solidly arranged, forming ovoid to spherical sub-nodules (Figure 1). Axonal degeneration with macrophage infiltration (gitter cells) allowed the identification of the so-called digestion chambers, which were observed in the optic tract by means of the hematoxylin and eosin staining and evidenced by the absence of Luxol Fast Blue staining (Figure 2A), compatible with the neurological signs observed in the clinical examination. In the right and left lateral geniculate nuclei there were focal areas with neuronal death caracterized by pyknotic and peripheral nuclei and marginal Nissl substance (central chromatolysis) or pericarions with shrunken hypereosinophilic and pyknotic nuclei (Figure 2B). The astrocytes were aty- 


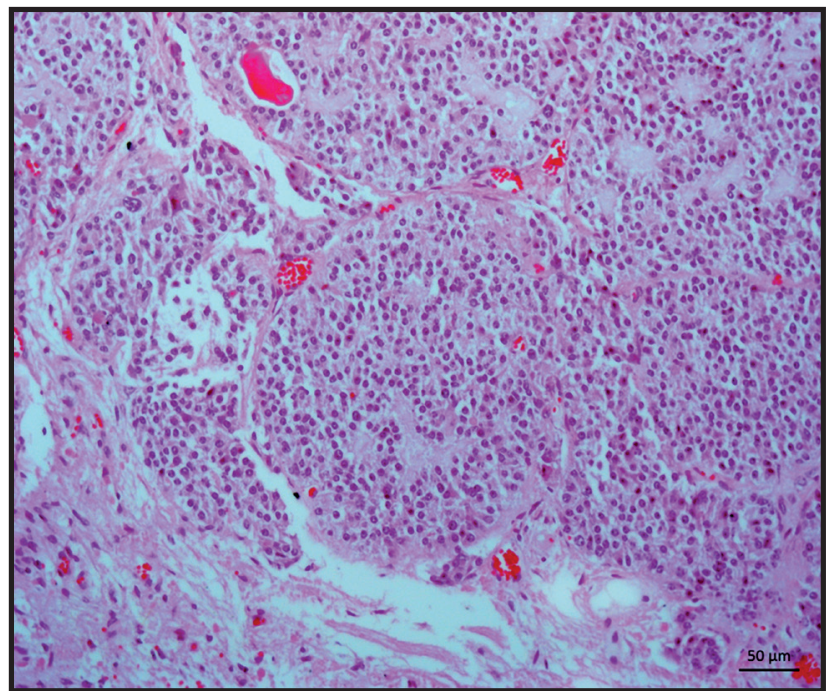

Figure 1. Pars intermedia with microadenomas composed by polyhedral to ovoid cells with basophilic and clear material compressing the pars nervosa [HE, obj.20x].

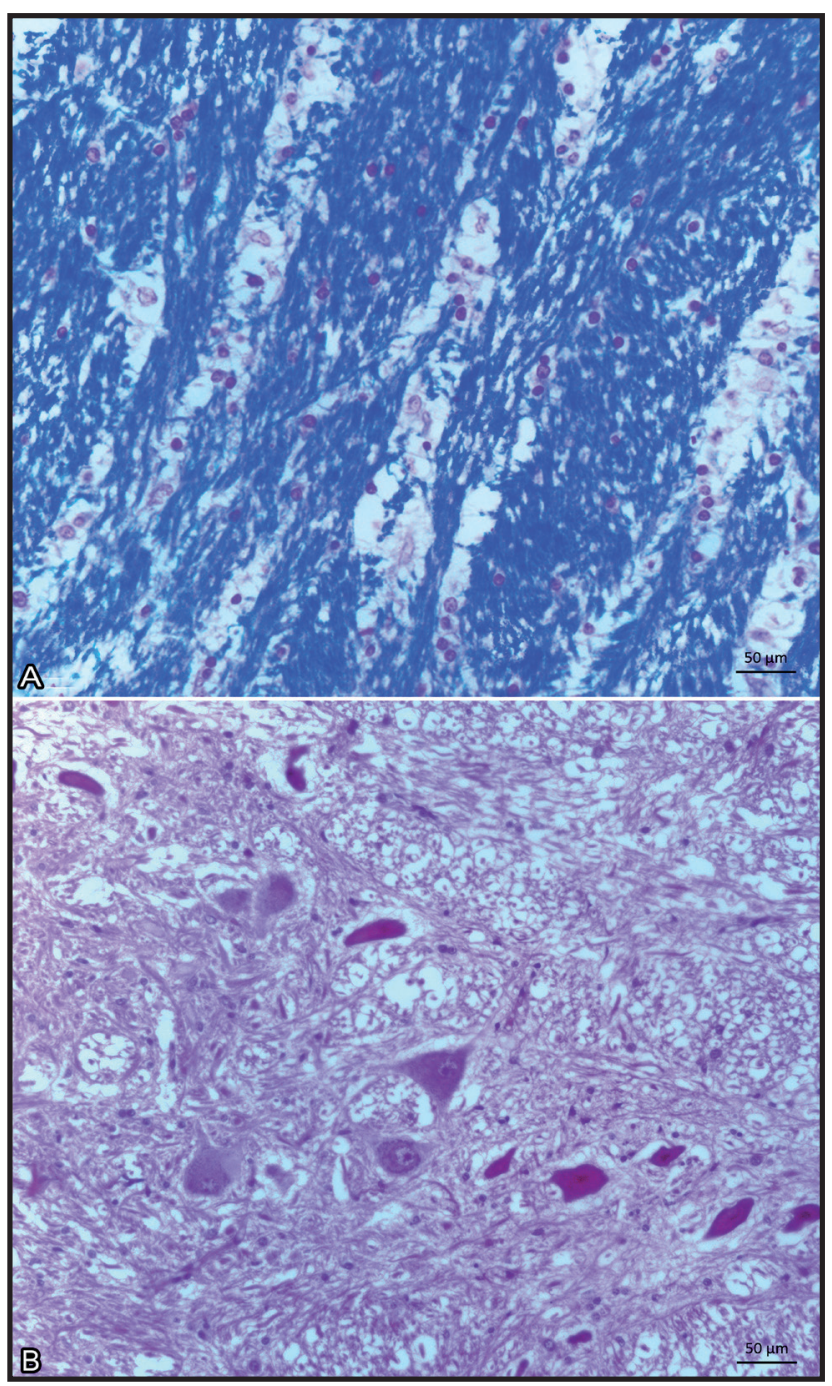

Figure 2. A- Dilation of myelin sheaths and macrophages in the optic tract with demyelination [Luxol Fast Blue; obj.20x]. B- Geniculate nuclei with shrunken hypereosinophilic pericarion and pyknotic nuclei (neuronal death) at rigth [HE; obj.20x]. pical and reactive, with an increase in volume, evident cytoplasm, and nuclei with marginal chromatin that sometimes were reniform. A yellowish orange pigment was observed in the pericary (lipofuscinosis) in many neurons of several areas of the central nervous system and trigeminal ganglion.

\section{DISCUSSION}

The central and bilateral blindness was associated with optic tract compression caused by the neoplastic mass, with consequent neuronal cell death in the lateral geniculate nucleus. A case similar to that of a 21-year-old horse in which a pars intermedia adenoma compressed vision-related neural structures and caused central blindness [26]. Central blindness was described as associated with optic tract compression in an equine by virtue of an ossifying fibroma located at the base of the skull that advanced to the sinuses and asymmetrically compressed the optic nerves, rostral to the optic chiasm [3].

Upon investigating the causes of blindness, the neural visual pathway should be investigated to evaluate the causes and consequences of injuries $[15,23]$. Sending eye globes and periocular tissues for histopathology in the diagnostic routine in Brazil is still an incipient practice that needs to be encouraged $[5,10]$. In the case reported, a marked demyelination in the optic tract and neuronal death in the lateral geniculate nucleus were found, which explains the clinical presentation of blindness. Upon finding an increased pituitary or other increased masses in the brain, compression of adjacent structures should be investigated $[3,23,26]$. Blindness is rarely associated with pituitary tumors in equine, although it is commonly reported in humans with pituitary neoplasia [26].

Differential diagnoses of blindness in equine should be considered, such as compressive masses caused by lymphosarcoma $[11,20]$ or other neoplasms [3], cholesterol granulomas [25], rabies [14], leukoencephalomalacia [4,19], trypanosomiasis by Trypanosoma evansi infection [17,18], equine herpesvirus myeloencephalopathy type 1 [14], equine protozoal myeloencephalitis (EPM), Eastern, Western, and Venezuelan equine encephalitis [2], West Nile virus infection [22], infestation of Halicephalobus gingivalis [1], brain abscess [15], lesions due to ingestion of mycotoxin-contaminated foods [19], medication [24] or trauma [16]. The absence of inflammatory lesions 3 
pathway of the equine presented in this report was an important morphological finding to rule out the other causes of blindness.

According to the morphology [9], this case is classified as stage 4 , where the increased PI compresses both pars nervosa and pars distalis and is not distinctly delimited between them. In addition, microadenomas in the neoplastic area and multiple follicles of irregular size composed of colloids were observed.

The most common disorder affecting the endocrine system of equines, particularly animals of advanced age, is pituitary pars intermedia dysfunction (PPID), which commonly results in Cushing's disease $[6,7,12,21]$. The mare examined in this case report presented infertility. Cases of pituitary pars intermedia dysfunction (PPID) reveal that decreased dopaminergic regulation of reproductive hormone release may contribute to infertility and is sustained when pergolide treatment in mares with PPID restores reproductive function and normal cycling [7]. Dopamine plays a major role in the production of $\mathrm{GnRH}$ in the hypothalamus, which will be released for $\mathrm{LH}$ and FSH production. When this production does not occur, the gonadotropin levels are reduced [8]. The equine in this case report was 18 years old. Advanced age, in the absence of other diseases, culminates in a level of dopaminergic neurodegeneration with signs similar to those found in cases of humans with Parkinson's disease. Functional dopaminergic neurons decrease with age and interfere with hormone synthesis reactions. One of the hypotheses concerning the triggers of dysfunction in the hormonal reaction of melanotropic cells is age-related dopamine cell loss, which is represented by the accumulation of lipofuscin in histological sections of the pituitary and central nervous system tissue, commonly observed in cases of PI adenoma [6]. Lipofuscinosis was also observed in the neuronal cell bodies of the equine presently reported.

This atypical case of acute blindness presented with a diagnosis of pituitary neoplasia may result in extraocular blindness due to neural compression; it should be considered in differential diagnoses of diseases causing blindness in horses.

Declaration of interest. The authors report no conflicts of interest. The authors alone are responsible for the content and writing of the paper.

\section{REFERENCES}

1 Bryant U.K., Lions E.T., Bain F.T. \& Hong C.B. 2006. Halicephalobus gingivalis-associated meningoencephalitis in a Thoroughbred foal. Journal of Veterinary Diagnostic Investigation. 18(6): 612-615.

2 Campos K.F., De Oliveira C.H.S., Belo Reis A., Yamasaki E.M., Brito M.F., Andrade S.J.T., Duarte M.D. \& Barbosa J.D. 2013. Surto de encefalomielite equina Leste na Ilha de Marajó, Pará. Pesquisa Veterinária Brasileira. 33(4): 443-448.

3 Madrigal R.G., Friedemann M.C., Vallone M.J., Ruoff C.M., Vallone L.V., Laughrey T., Rech R.R. \& Coleman M.C. 2018. Ossifying fibroma as a cause of blindness in a 5-year-old Quarter Horse gelding. Equine Veterinary Education. DOI: $10.1111 /$ eve.12944

4 Marcolongo-Pereira C., Estima-Silva P., Soares M.P., Sallis E.S.V., Grecco F.B., Fernandes C.G., Raffi M.B. \& Schild A.L. 2014. Doenças de equinos na região Sul do Rio Grande do Sul. Pesquisa Veterinária Brasileira. 34(3): 205-210.

5 Martins T.B. \& Barros C.S.L. 2014. Fifty years in the blink of an eye: a retrospective study of ocular and periocular lesions in domestic animals. Pesquisa Veterinária Brasileira. 34(12): 1215-1222.

6 Mcfarlane D. 2007. Advantages and limitations of the equine disease, pituitary pars intermedia dysfunction as a model of spontaneous dopaminergic neurodegenerative disease. Ageing Research Reviews. 6(1): 54-63.

7 Mcfarlane D. 2011. Equine pituitary pars intermedia dysfunction. Veterinary Clinics: Equine Practice. 27(1): 93-113.

8 Medeiros S.F. \& Medeiros M.M.W.Y. 2007. Modificações dos níveis de gonadotrofinas durante a vida reprodutiva. Revista brasileira de ginecologia e obstetrícia. 29(1): 48-55.

9 Miller M.A., Pardo I.D., Jackson L.P., Moore G.E. \& Sojka J.E. 2008. Correlation of pituitary histomorphometry with adrenocorticotrophic hormone response to domperidone administration in the diagnosis of equine pituitary pars intermedia dysfunction. Veterinary Pathology. 45(1): 26-38.

10 Moreira M.V.L., Teixeira Neto R.L.A.L., Langohr I.M. \& Ecco R. 2018. Prospective study of ocular and periocular diseases in animals: 188 cases. Pesquisa Veterinária Brasileira. 38(3): 502-510. 
11 Oliveira M.C., Faleiro R.D., Santos C.C.A., Oliveira G.F., Daoualibi Y., Sonne L., Brito M.F. \& Ubiali D.G. 2016. Linfoma de células T multicêntrico e ocular em equino. Revista Brasileira de Medicina Veterinária. 38(Supl. 2): 147-151.

12 Pease A.P., Schott II H.C., Howey E.B. \& Patterson J.S. 2011. Computed tomographic findings in the pituitary gland and brain of horses with pituitary pars intermedia dysfunction. Journal of Veterinary Internal Medicine. 25(5): 1144-1151.

13 Pierezan F., Rissi D.R., Rech R.R., Fighera R.A., Brum J.S. \& Barros C.S.L. 2009. Achados de necropsia relacionados com a morte de 335 eqüinos: 1968-2007. Pesquisa Veterinária Brasileira. 29(3): 275-280.

14 Pimentel L.A., Oliveira D.M., Galiza G.J.N., Rego R.O., Dantas A.F.M. \& Riet-Correa F. 2009. Doenças do sistema nervoso central de equídeos no semi-árido. Pesquisa Veterinária Brasileira. 29(7): 589-597.

15 Rech R. \& Barros C. 2015. Neurologic Diseases in Horses. Veterinary Clinics of North America: Equine Practice. 31: 281-306.

16 Reppas G.P., Hodgson D.R., McClintock S.A. \& Hartley W.J. 1995. Trauma-induced blindness in two horses. Australian Veterinary Journal. 72(7): 270-272.

17 Rodrigues A., Fighera R.A., Souza T.A., Schild A.L., Soares M.P., Milano J. \& Barros C.S.L. 2005. Surtos de tripanossomíase por Trypanosoma evansi em eqüinos no Rio Grande do Sul: aspectos epidemiológicos, clínicos, hematológicos e patológicos. Pesquisa Veterinária Brasileira. 25: 239-249.

18 Rodrigues A., Fighera R.A., Souza T.M., Schild A.L. \& Barros C.S.L. 2009. Neuropathology of naturally occurring Trypanosoma evansi infection of horses. Veterinary Pathology. 46(2): 251-258.

19 Ross P.F., Ledet A.E., Owens D.L., Rice L.G., Nelson H.A., Osweiler G.D. \& Wilson T.M. 1993. Experimental equine leukoencephalomalacia, toxic hepatosis, and encephalopathy caused by corn naturally contaminated with fumonisins. Journal of Veterinary Diagnostic Investigation. 5(1): 69-74.

20 Sano Y., Okamoto M., Ootsuka Y., Matsuda K., Yusa S. \& Taniyama H. 2017. Blindness associated with nasal/ paranasal lymphoma in a stallion. Journal of Veterinary Medical Science. 79(3): 579-583.

21 Schott 2nd H.C. 2002. Pituitary pars intermedia dysfunction: equine Cushing's disease. The Veterinary Clinics of North America: Equine Practice. 18(2): 237-270.

22 Silva A.S.G., Matos A.C.D., Cunha M.A.C.R., Rehfeld I.S., Galinari G.C.F., Marcelino S.A.C., Saraiva L.H.G., Martins N.R.S., Maranhão R.P.A., Lobato Z.I.P., Pierezan F., Guedes M.I.M.C. \& Costa E.A. 2018. West Nile virus associated with equid encephalitis in Brazil. Transboundary Emerging Diseases. 2019; 66: 445-453. https://doi. org/10.1111/tbed.13043

23 Summers B.A., Cummings J.F. \& De Lahunta A. 1995. Tumors of the central nervous system. In: Veterinary Neuropathology. St Louis: Mosby-Year Book, pp.380-385.

24 Swor T.M., Whittenburg J.L. \& Chaffin M.K. 2009. Ivermectin toxicosis in three adult horses. Journal of the American Veterinary Medical Association. 235(5): 558-562.

25 Tofflemire K.L., Whitley R.D., Wong D.M., Waller 3rd K.R., Myers R.K., Pillatzki A.E. \& Ben-Shlomo G. 2013. Episodic blindness and ataxia in a horse with cholesterinic granulomas. Veterinary Ophthalmology. 16(2): 149-152.

26 Wallace M.A., Crisman M.V., Pickett J.P., Carrig C.B. \& Sponenburg D.P. 1996. Central blindness associated with a pituitary adenoma in a horse. Equine Practice. 18: 8-13. 